\title{
THE GEOLOGY OF THE FISKENÆSSET REGION
}

\author{
F. Kalsbeek and J. S. Myers
}

\section{Introduction}

In 1955 Grønlands Geologiske Unders $\varnothing$ gelse (The Geological Survey of Greenland, GGU) started the systematic mapping of the west coast of Greenland. Up to 1963 the work was concentrated in the southernmost part of Greenland, around Nanortalik, Julianehåb and Ivigtut, from 1958 to 1963 from a base camp, 'Dyrnæs' near Narssaq. In 1964 the base camp was moved northwards to a site near Frederikshåb, 'Mellembygd', and from 1964 to 1968 the region around Frederikshåb was mapped, as far north as Frederikshåbs Isblink. In 1969 the base camp was moved still further north, to 'Midgård', $15 \mathrm{~km}$ north-north-east of Fiskenæsset, and in 1970 mapping in the Fiskenæsset Region commenced. Mapping of the area between Frederikshåbs Isblink and Fiskenæsfjorden (an area of about $2500 \mathrm{~km}^{2}$ ) is now almost finished, and a simplified map is presented on plate 1. This paper attempts to give an outline of the geology of the area.

The Fiskenæsset region is part of the old gneiss block of south Greenland (Pulvertaft 1968), and the area is of special interest because very old rocks, most probably in the order of 3000-4000 m.y. old (Black et al. 1971, Pidgeon, this issue), are extremely well exposed here and can be studied in detail.

The final results of the mapping will be presented on 1:100 000 map sheets, but the field mapping is being done on excellent 1:20 000 sheets prepared by the Geodetic Institute and Aerokort $\mathbf{A} / \mathbf{S}$, and on aerial photographs at a scale of approx. 1:40 000 enlarged to 1:20 000, which permit detailed mapping.

Since access to the area is difficult extensive use is made of helicopters, especially in the higher and inland part of the area, and of small cutters in the coastal part with its numerous islands.

Reconnaissance mapping of the coastal areas has been made on several occasions before the systematic mapping of the area started in 1970. In 1878 Kornerup travelled through the area by umiak (Eskimo boat rowed by women) and Kornerup's map (Kornerup 1879) already showed such features as the Ravns Storø amphibolite belt (see p. 37) and the Ilivertalik granite (see p. 10). In 1952 Ellitsgaard-Rasmussen made a reconnaissance in the Fiskenæsset area and the anortho- 
sitic rocks of the area appear for the first time on his unpublished maps. A more detailed reconnaissance was performed by Windley from 1964 to 1967 . Windley's maps and descriptions, although now partly outdated, have proved a great help during the current mapping.

\section{Main rock types and the average mineralogical and chemical composition of the area}

The main rock types of the Fiskenæsset area are gneisses, amphibolites, and rocks of the anorthosite complexes (also called the 'Fiskenæsset complex'). The gneisses consist essentially of plagioclase, quartz and varying, but often small, amounts of microcline and biotite. The amphibolites consist of hornblende and plagioclase, often with some quartz, and the rocks of the anorthosite complexes consist of very calcic plagioclase (mainly bytownite) with varying amounts of hornblende and some diopside and biotite. All these rock types have in many places been migmatised to varying degrees; in parts of the area the amphibolites and anorthosites have been so strongly migmatised that they now occur only as inclusions within gneissic quartzo-feldspathic material. The rocks of the area are generally very inhomogeneous on a small scale because gneisses of different compositions and amphibolites often occur together in the same outcrop and have often been partially migmatised. In the northern part of the area, especially in the region around Midgård, the rocks often contain hypersthene.

Table 1. Estimated average composition of the bedrock of the Fiskencesset region

\begin{tabular}{|c|c|c|c|c|c|}
\hline $\mathbf{A}$ & & B & & $\mathrm{C}$ & \\
\hline \multirow[t]{2}{*}{ gneisses } & $83 \%$ & quartz & $27 \%$ & $\mathrm{SiO}_{2}$ & 66.2 \\
\hline & & plagioclase * & $49 \%$ & $\mathrm{TiO}_{2}$ & 0.6 \\
\hline \multirow[t]{2}{*}{ amphibolites } & $12 \%$ & K-feldspar & $7 \%$ & $\mathbf{A l}_{2} \mathbf{O}_{3}$ & 15.2 \\
\hline & & biotite & $6.5 \%$ & $\mathrm{Fe}_{2} \mathrm{O}_{3}$ & 1.3 \\
\hline \multirow[t]{6}{*}{ anorthosites and associated rocks } & $5 \%$ & hornblende & $8 \%$ & $\mathrm{FeO}$ & 3.1 \\
\hline & & epidote & $1.5 \%$ & $\mathrm{MgO}$ & 2.3 \\
\hline & & hypersthene & $1 \%$ & $\mathrm{CaO}$ & 4.1 \\
\hline & & clinopyroxene & $0.5 \%$ & $\mathrm{Na}_{2} \mathrm{O}$ & 3.9 \\
\hline & & magnetite & $0.6 \%$ & $\mathbf{K}_{2} \mathbf{O}$ & 2.0 \\
\hline & & ilmenite & $0.3 \%$ & & $\overline{98.7}$ \\
\hline
\end{tabular}

* mean An $27 \%$
A Amounts of the different rock types ( $\%$ by volume)
B Average mineralogical composition ( $\%$ by volume)
C Average chemical composition ( $\%$ by weight) 


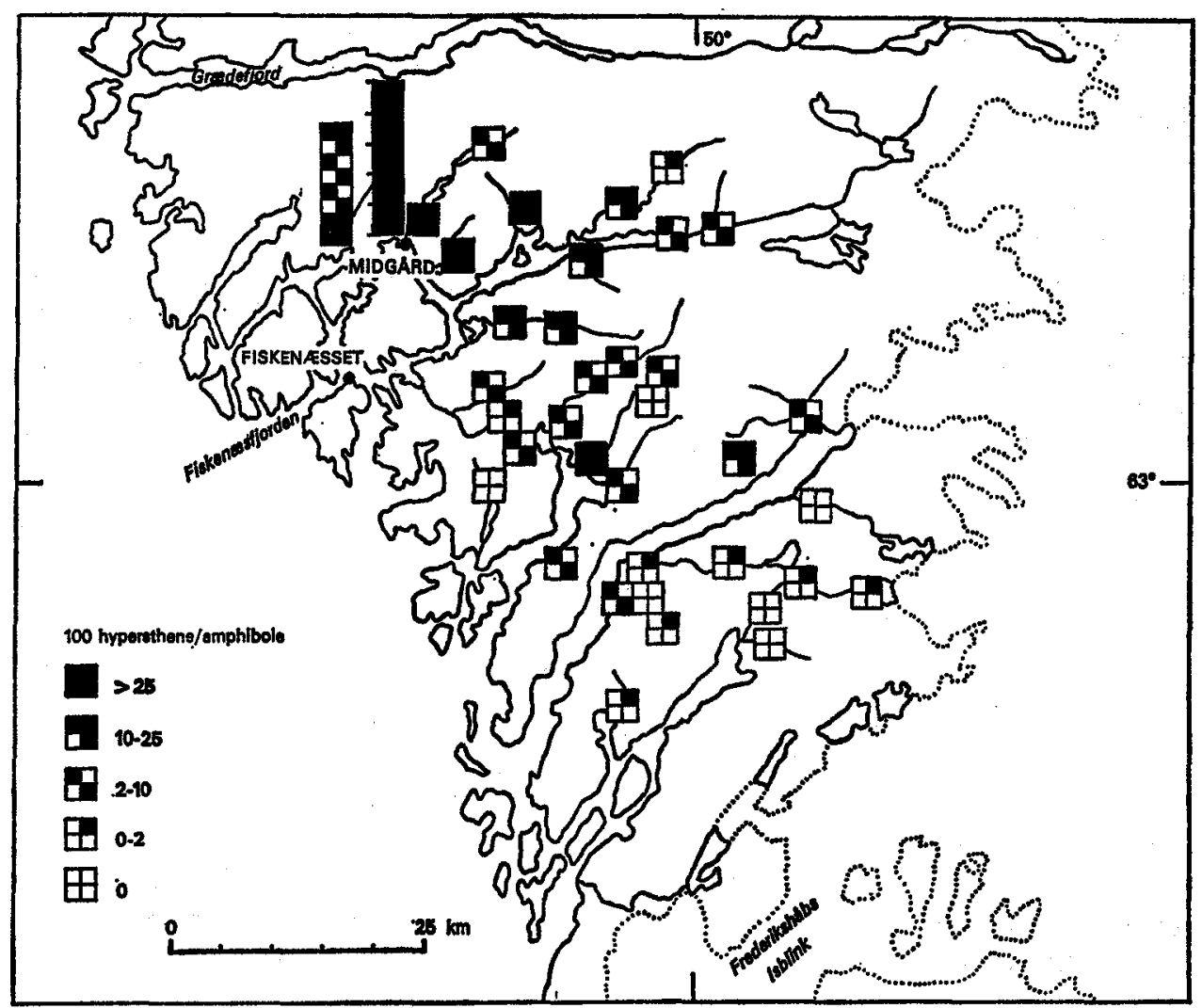

Fig. 1 The hypersthene contents of sand samples from the Fiskenxsset region give an impression of the metamorphic grade of the rocks in the area. Hornblende granulite facies rocks occur mainly in the north-western part of the area. Towards the south-east the metamorphic grade decreases.

Hypersthene/amphibole ratios determined in grain counts (Kalsbeek et. al. in press).

The amounts of the different rock types in the area and the average mineralogical and chemical composition of the rocks have been estimated with the help of a regional study of sand samples (Kalsbeek et al. in press) and are shown in table 1 . These estimates of the three main rock types agree with estimates based on the geological map (plate 1) and on a grid sample collection.

The estimated average chemical composition agrees well with the estimates for other shield areas given by Ronov \& Yaroshevsky (1969). The estimated composition in terms of rock types seems to be more or less representative of most of the old gneiss block which outcrops for about $600 \mathrm{~km}$ along the west coast of Greenland, except that anorthositic rocks are less common elsewhere.

The metamorphic grade of the rocks can also be estimated from the composi- 
tion of the sands (fig. 1). Hypersthene-rich sands occur mainly in the northern part of the area and the hypersthene content gradually but irregularly decreases in a southerly direction. Together with the hypersthene content, the amount of diopside and opaque minerals (both magnetite and ilmenite) also decreases in a southerly direction whilst the amount of epidote and sphene increases. These changes in the sands are evidently related to the metamorphic grade of the bedrock which decreases from hornblende granulite facies in the north to (low?) amphibolite facies in the south. The average chemical composition of the sands, however, is almost identical in the northern, central and southern parts of the area, the only difference being an increasing oxidation ratio towards the south.

In the following paragraphs the main rock types are briefly described.

\section{Gneisses}

The gneisses of the Fiskenæsset area vary from very homogeneous types to clearly banded (biotite banded, pegmatite banded and amphibolite banded) and veined gneisses. The homogeneous gneisses have generally been called 'granite' in the field, but vary in composition from granite to tonalite. The name 'streaky gneiss' has been used as a field term covering most of the banded and veined gneisses. In many cases the streaky gneisses contain little or no microcline. The mineralogical composition of a number of gneiss samples is shown in fig. 2 and some chemical compositions in table 2 . For the sake of brevity the terms 'granite' and 'streaky gneiss', as defined above, will be used in the following text.
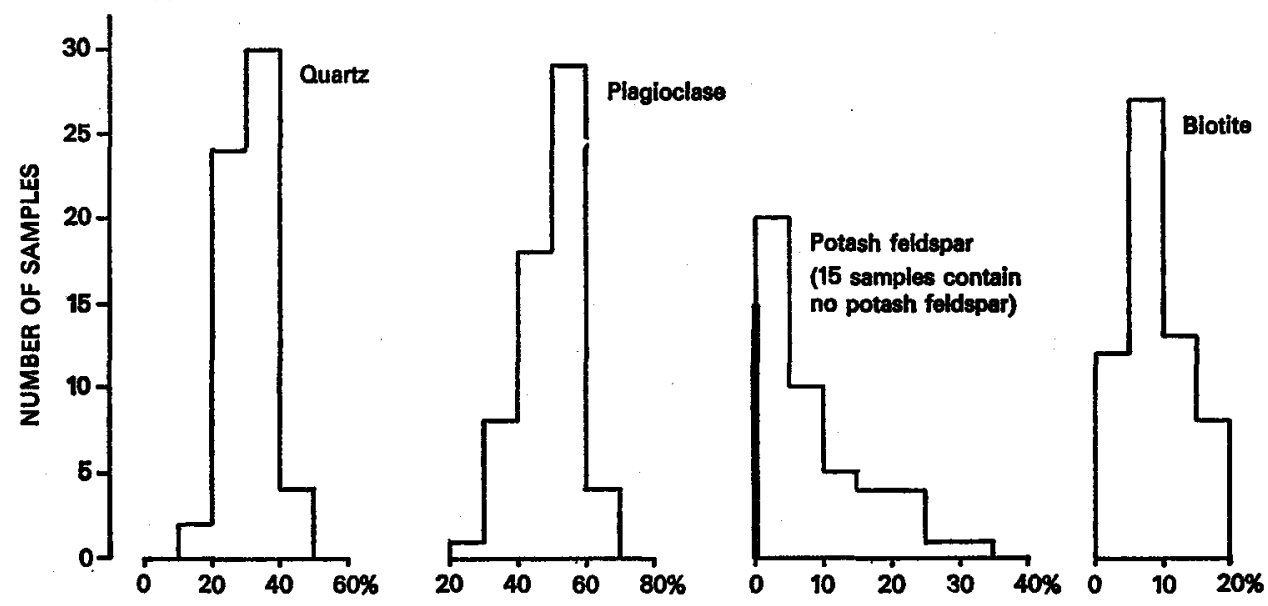

Fig. 2 Histograms of the quartz, plagioclase, potash feldspar and biotite contents in 60 gneisses from the Fiskenæesset region. Modal analyses by J. R. Thomas (this issue table 5) and L. S. Andersen (pers. comm.). 


\section{$a$}

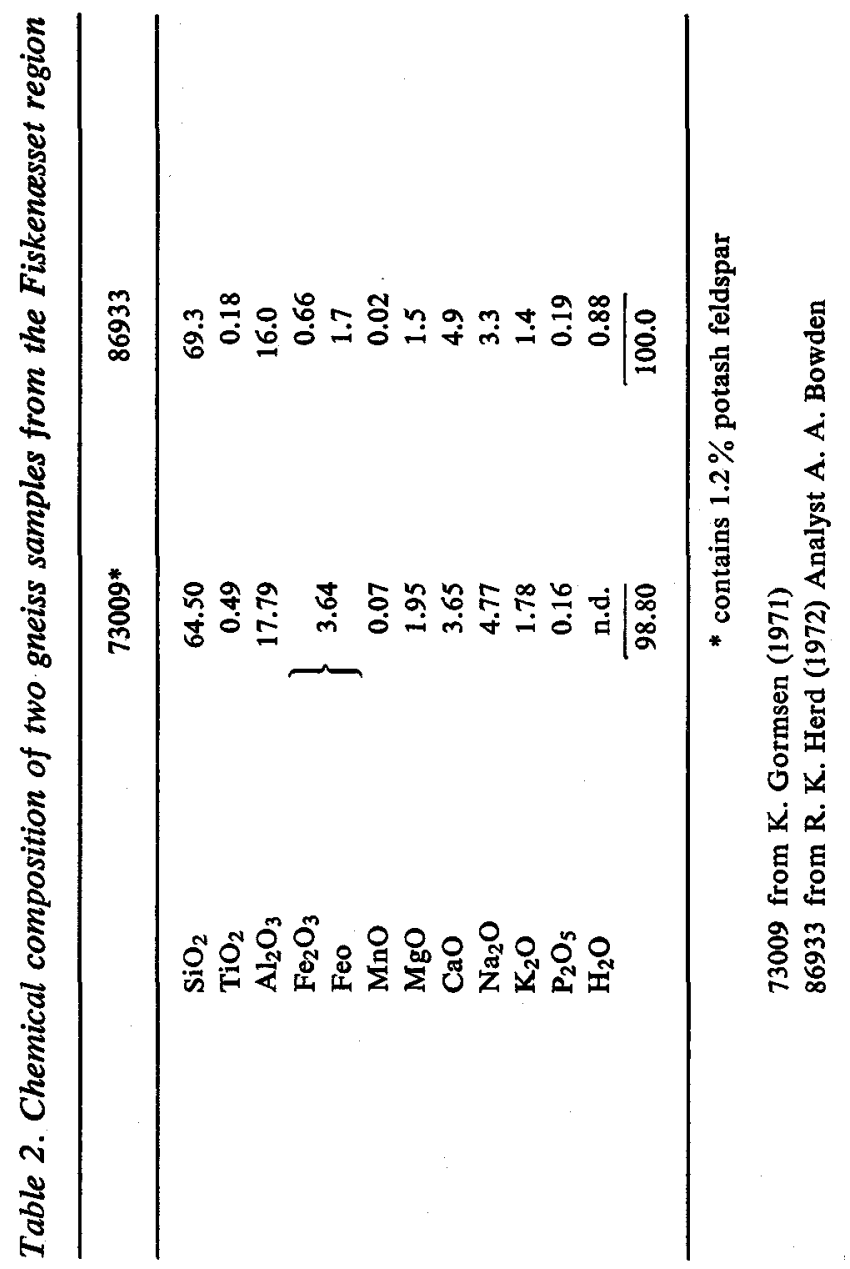

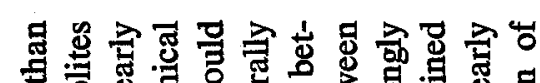

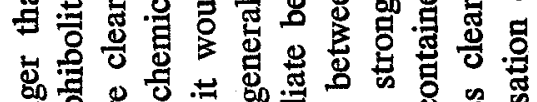
然遂要

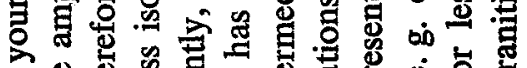

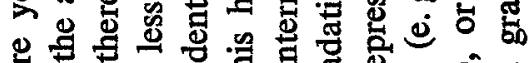
ส

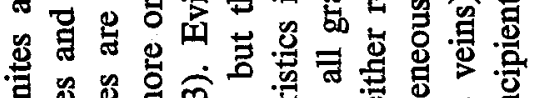

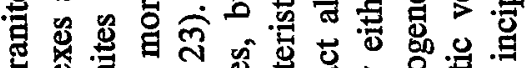

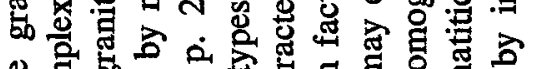

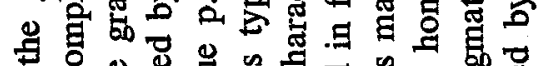

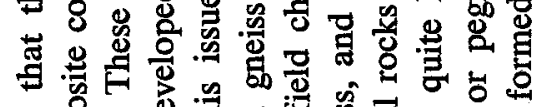

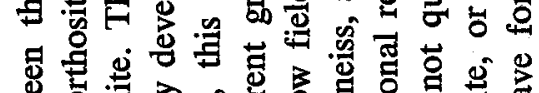

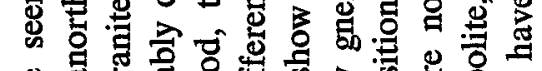

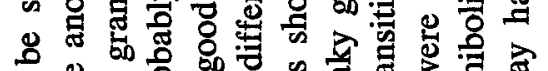

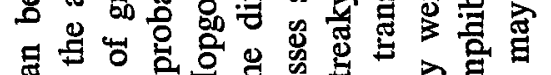

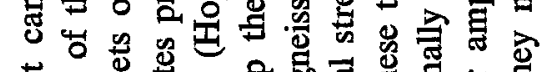

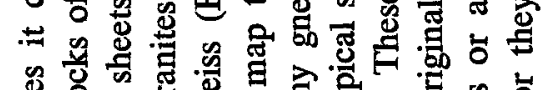

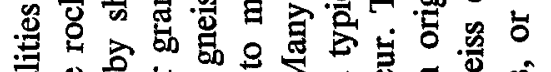

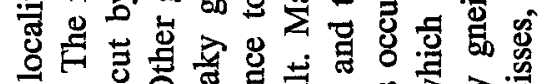

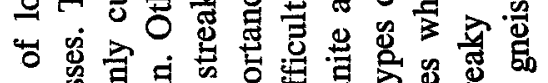

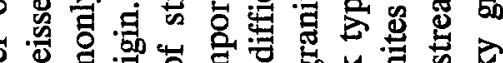

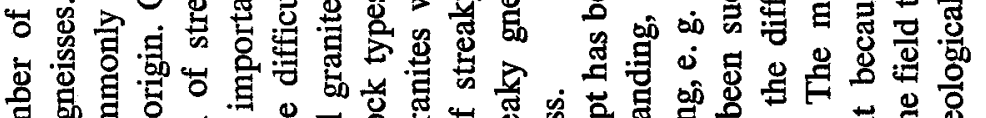
刍

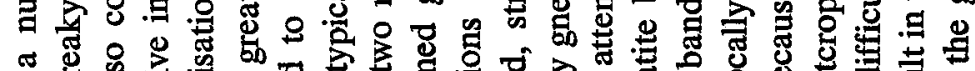

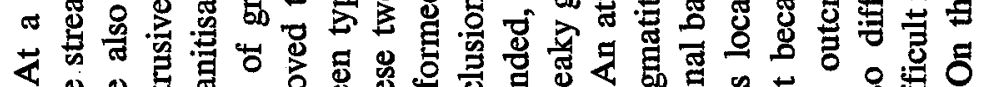

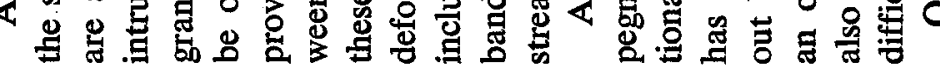

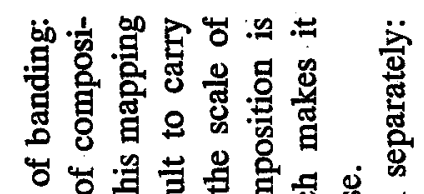

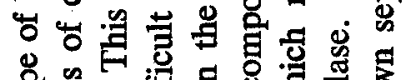

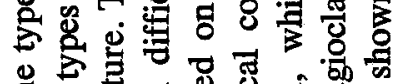

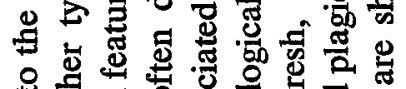
कo 항 च

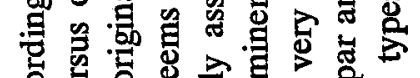

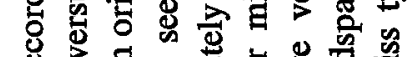

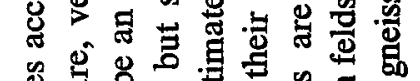

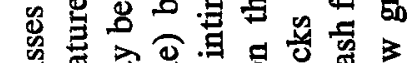

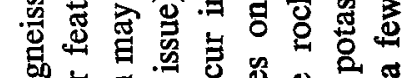

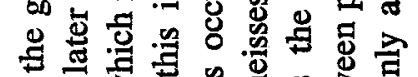

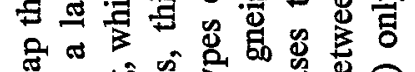

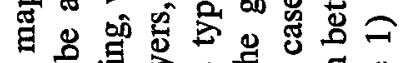

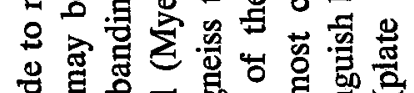

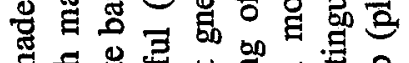

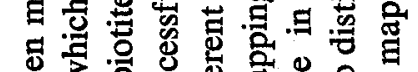

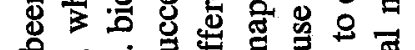


the (par)autochthonous granodioritic gneisses ('granites') and homogeneous quartz dioritic and granitic gneisses associated with large amphibolite belts both in the southern part of the area; intrusive granites in the northern part of the region, and local occurrences of apparently metasedimentary gneisses.

\section{Origin of the streaky gneisses}

In 1970 minor occurrences of marble were found by Hopgood (this issue) and by Rivalenti within the streaky gneisses. Some of these marbles are interlayered with calc-silicate gneiss and with well-banded, streaky, biotite gneiss which often contains some calcite. Studies of the trace elements in these marbles and the surrounding gneisses indicate that the marbles have not been derived from carbonatitic rocks. This is corroborated by trace element data from early, discordant, carbonatitic veins found by Hopgood in the same area. These carbonatitic veins contain much larger amounts of $\mathrm{Sr}, \mathrm{Ba}, \mathrm{Zr}, \mathrm{Y}$ and $\mathrm{La}$. In 1971, Myers (this issue) and Rivalenti found zones of brownish weathering gneisses within the streaky gneisses which contain garnet and sillimanite, and bands of magnetite-bearing quartzites. These rocks probably represent metasediments and they grade both along and across their strike into normal streaky gneiss. These observations indicate that part of the streaky gneisses is probably of metasedimentary origin. The occurrence of such rocks of probable metasedimentary origin is however very rare and they do not prove that all, or even most, of the streaky gneisses have been derived from metasediments.

\section{Origin of the homogeneous gneisses}

It has been mentioned above that part of the granites seems to have been derived from streaky gneisses by granitisation (or homogenisation). According to Hopgood (this issue) this granitisation took place along specific stratigraphical horizons and was probably dependent upon the original composition of the rocks. Other granites are clearly intrusive, and locally several phases of granitic igneous activity can be demonstrated. Some of the instrusive granites contain large amounts of potash feldspar but others have a tonalitic composition and resemble the streaky gneiss both in chemical and mineralogical composition. It is not yet possible to say what proportions of these granites could have been derived by anatexis from streaky gneisses.

\section{Ilivertalik granite}

The high mountain of Ilivertalik $(1130 \mathrm{~m})$ near Midgård, on which Midgård's radio station is situated, consists largely of a very homogeneous, relatively coarsegrained, brownish weathering hypersthene-bearing, augen gneiss of granitic com- 
position. This Ilivertalik granite locally contains inclusions of migmatised streaky gneiss, amphibolite and rocks of the anorthosite complex, but is itself cut by dykes of fine-grained, white 'granite', which seem to be comparable with some of the instrusive 'granites' found elsewhere in the area. The Ilivertalik granite has been strongly deformed; parts of it possess a strongly marked, steeply plunging linear fabric. In other places especially along its contacts with streaky gneisses, there is the development of a planar fabric and locally this planar fabric is very marked and the rock grades into mylonite. Kornerup (1879) was the first to mention the presence of this granite with its characteristic feldspar augen with carlsbad twins.

No large outcrops of granitic gneisses of this type have been found within the area mapped until now, but they occupy large areas in the terrain farther to the north. The homogeneity of these rocks and their sharply cross-cutting relationships with the older migmatites suggest that they represent intrusive granites which were emplaced during the later stages of the plutonic history of the area.

\section{Anorthosite complexes}

The anorthositic rocks of the Fiskenæsset area were discovered by $\mathrm{K}$. EllitsgaardRasmussen in 1952 (unpublished reconnaissance map). The origin of these, and other anorthositic rocks found in southern West Greenland around that time, was not clear. Sørensen (1955) considered a sedimentary, possibly calcareous, origin likely for the anorthosite of Buksefjorden (approx. $90 \mathrm{~km}$ north of Fiskenæsset), and Ramberg (1952) suggested that regional basification in the deeper parts of the crust might explain the origin of the West Greenland anorthosites.

During reconnaissance mapping for GGU, Windley in 1964 discovered the presence of numerous chromitite layers in the anorthosite. This chromitite layering and other types of layering, led Windley (1967) to the conclusion that the anorthositic rocks of the Fiskenæsset area represent gravity stratified igneous rocks. This conclusion has been confirmed by later investigations. Further descriptions of the anorthositic and associated rocks have been given by Windley (1969) and by Windley et al. (in press). The chromite deposits associated with the anorthosite complexes have been described by Ghisler \& Windley (1967) and by Ghisler (1970).

The anorthosite complexes or "Fiskenæsset complex" consist of various rock types of which meta-anorthosites are the most characteristic. Ultramafic rocks (mainly hornblende-bearing peridotites) and meta-gabbroic rocks as well as metaleucogabbros are also important. According to Windley et al. (in press) the average composition of the complex on the island of Qeqertarssuatsiaq is that of an anorthositic gabbro with some $30 \%$ of mafic minerals in the norm. This average composition of the complex may, however, change from place to place. Large outcrops may consist almost completely of meta-anorthosite without as- 
sociated mafic rocks; others consist almost exclusively of meta-gabbros without much anorthosite. From the composition of a series of sand samples collected along a river running through the large Majorqap qâva outcrop (Kalsbeek et al. in press) an estimated average of $17 \%$ mafic minerals and $83 \%$ of calcic plagioclase can be calculated for the anorthositic and associated rocks there. This outcrop consists mainly of meta-leucogabbros with some $20 \%$ of hornblende and meta-anorthosite, with minor amounts of gabbroic rocks.

In 1970, during the present systematic mapping of the Fiskenæsset area Windley found that the anorthosite complex on Qeqertarssuatsiaq and the adjoining areas has a more or less constant stratigraphy (Windley 1971). Very simplified, the complex shows the following sequence of layers from (what later proved to be) the bottom upwards: (1) ultramafic rocks, (2) layered anorthositic and (leuco-) gabbroic rocks, ranging upwards into (3) leucogabbroic rocks, often with coarse gabbroic textures, which finally give away to (4) anorthositic rocks which are locally garnetiferous. The hornblende chromitite layers were found to occur only in the upper, locally garnetiferous, anorthosite unit, i. e. near the top of the intrusion. Already during the 1970 field season this stratigraphy proved to be very useful in the search for chromite layers. However, it also became evident that not all known anorthosite outcrops show the same stratigraphy.

By mapping the stratigraphy of the anorthosite complex on Qeqertarssuatsiaq, Windley showed that most of the anorthositic rocks which appear on the map as single units, have a symmetrical arrangement of their stratigraphical elements in the form of tightly compressed isoclinal folds. At the same time (summer 1970) analyses of rocks from the complex were made by Bowden (Windley et al. op. cit.) and these analyses showed that there are clear chemical trends across the stratigraphy, which, by their symmetrical arrangement about the centre, independently indicated that the anorthosite outcrops represent isoclinal folds. Bowden's analyses also indicated the primary way-up of the complex. On Qeqertarssuatsiaq the bottom layers of the complex occur along the margins of the outcrop and the top layers with the chromitite occurrences in the centre, the anorthositic rocks thus forming a syncline.

In general, the anorthosite outcrops in the eastern part of the area seem to be less severely deformed than those in the coastal areas, and they generally do not seem to form isoclinal structures. Remnants of igneous textures and well-preserved igneous layering have been found throughout most of the complex, but are more common in the eastern part of the region (Myers, this issue; Walton, this issue). In a number of examples the way-up can be determined in the field from these primary structures.

The anorthositic and associated rocks are by far the best investigated rocks in the area. A wealth of petrological, geochemical and mineral chemical information has been collected (Windley et al., in press; Windley, this issue; Windley \& Smith, in press). It has been concluded (Windley et al. op. cit.) that the anorthosite 
complexes formed from a water-rich magma, which should explain, for example, why the chromitite layers occur near the top of the intrusion and not, as elsewhere in layered intrusions, near the bottom.

Associated with the anorthosite complexes, outcrops of exotic rock types occur, containing such rare minerals as sapphirine, kornerupine and ruby corundum. These outcrops almost invariably occur at the contact between the top of the anorthosite complex and the bordering amphibolites, and the rocks apparently formed by metasomatic processes between the anorthosites and the adjoining rocks. A thorough study of these rocks has been undertaken by Herd (1972 and this issue).

The anorthosites of the Fiskenæsset region are often fringed by amphibolite. In earlier papers on the complex, it was assumed that these amphibolites represented original noritic gabbros and belonged to the complex itself. This has proved not to be the case. During the field work in 1970 it was found that these amphibolites locally contain layers of mica schist which suggested a supracrustal origin for the amphibolites. Moreover, chemical analyses have shown that the amphibolites do not fit into the differentiation trends for the rocks of the intrusive complex (Windley et al. op. cit.). It is now assumed that these amphibolites represent a supracrustal volcanic sequence into which the anorthositic rocks were emplaced.

\section{Amphibolites}

Approximately $10 \%$ of the area mapped until now consists of amphibolite. Most of the amphibolites occur as concordant layers or as inclusions within the gneisses. Discordant amphibolites such as those described by Dawes (1970) from the nunataks and semi-nunataks in the Frederikshåbs Isblink, and by McGregor (1973) from the Godthåb region, are very rare. Most amphibolites are massive, or finely banded, rather fine grained, black rocks, which in some places contain macroscopically visible garnet or diopside. In many cases the amphibolites have been strongly migmatized. No detailed investigation of the amphibolites has as yet been made. A few chemical and modal analyses are listed in table 3 .

The largest outcrop of amphibolitic rocks is the so-called Ravns Stor $\varnothing$ belt in the southern part of the area between Ravns Storø and Frederikshåbs Isblink (Andersen \& Friend, this issue). This belt has a maximum width of $4 \mathrm{~km}$ and consists of amphibolite with garbenschiefer texture together with minor greenschists and ultramafic rocks. Rocks of certain metasedimentary origin have not been found within the belt.

Some of the amphibolites of the Ravns Stor $\varnothing$ belt resemble metamorphosed volcanic tuffs and in others remnants of pillow structures have locally been found. Within these rocks of apparently supracrustal origin, metamorphosed gabbroic intrusives occur which show igneous layering and which often have well-preserved 
Table 3. Chemical and modal analyses of amphibolites and associated rocks from the Fiskencesset area (Gormsen 1971)

\begin{tabular}{|c|c|c|c|c|}
\hline & 73016 & 73086 & 73092 & 73093 \\
\hline $\mathrm{SiO}_{2}$ & 49.41 & 50.00 & 47.90 & 49.10 \\
\hline $\mathrm{TiO}_{2}$ & 1.02 & 1.48 & 0.71 & 1.56 \\
\hline $\mathrm{Al}_{2} \mathrm{O}_{3}$ & 15.17 & 14.06 & 16.64 & 15.19 \\
\hline $\mathrm{Fe}_{2} \mathrm{O}_{3}$ & 2.27 & 2.53 & 1.72 & 2.61 \\
\hline $\mathrm{FeO}$ & 8.85 & 10.88 & 6.72 & 10.17 \\
\hline $\mathrm{MnO}$ & 0.19 & 0.18 & 0.26 & 0.21 \\
\hline MgO & 6.78 & 6.83 & 4.80 & 6.27 \\
\hline $\mathrm{CaO}$ & 11.42 & 8.84 & 19.15 & 8.85 \\
\hline $\mathrm{Na}_{2} \mathrm{O}$ & 2.00 & 2.61 & 0.58 & 2.40 \\
\hline $\mathrm{K}_{2} \mathrm{O}$ & 0.28 & 0.48 & 0.02 & 1.48 \\
\hline $\mathrm{P}_{2} \mathrm{O}_{5}$ & 0.09 & 0.20 & 0.09 & 0.15 \\
\hline \multirow[t]{2}{*}{$\mathrm{H}_{2} \mathrm{O}$} & 0.96 & n.d & n.d & n.d \\
\hline & $\overline{98.43}$ & 98.9 & $\overline{98.59}$ & 97.99 \\
\hline plagioclase & 36.7 & 39.9 & 42.5 & 33.8 \\
\hline quartz & 8.8 & 13.9 & 1.8 & 10.9 \\
\hline K-feldspar & + & 5.8 & 0.4 & 0.2 \\
\hline hypersthene & 8.5 & - & 1.1 & - \\
\hline diopside & 13.6 & - & 51.3 & - \\
\hline hornblende & 31.7 & 39.2 & 1.1 & 44.9 \\
\hline biotite & - & - & - & 8.2 \\
\hline opaque & 0.7 & 1.4 & + & 0.2 \\
\hline garnet & - & - & + & - \\
\hline sphene & 0.1 & - & 1.7 & - \\
\hline
\end{tabular}

porphyritic textures. Towards the margins and the north-eastern extremity of the belt, the metamorphic grade of the rocks seems to increase and they grade into the typical massive or banded black amphibolites of the Fiskenæsset region.

At the north-eastern end of the Ravns Stor belt, the amphibolites are folded into a large recumbent synform, and in the northern limb of this fold they are strongly flattened. On the other side of Ikatoq fjord, similar amphibolites occur in the gneisses, and these seem to form a link between the Ravns Stor $\varnothing$ belt and the large amphibolite belt in the area south of Bjørnesund. Both the Ravns Stor $\varnothing$ belt and this second belt are associated with quartz dioritic gneisses and minor granites and it seems reasonable to correlate the two. Anorthositic rocks occur in the north-eastern part of the belt south of Bjørnesund. This evidence suggests that the supracrustal amphibolites which often fringe the anorthosite complexes correlate with the amphibolites of the Ravns Stor $\varnothing$ belt. Also most of the other amphibolites which occur throughout the area are lithologically similar to those associated with the anorthosite complexes, and may be of supracrustal origin and have broadly the same age as the Ravns Stor $\varnothing$ amphibolites. 
It has previously been suggested (Windley 1969) that the Ravns Stor $\varnothing$ amphibolites are younger than the surrounding gneisses and were down-folded into them in a so-called linear belt, within which the gneisses were down-graded from original granulite facies to amphibolite facies mineral assemblages. This suggestion has proved to be incorrect. There is no evidence to show that the Ravns Stor $\varnothing$ amphibolites form a syncline in the gneisses, nor that they are younger than the surrounding gneisses, nor that the latter have been granulite facies rocks (see Andersen \& Friend, op. cit.).

At their boundaries with the neighbouring gneisses, the amphibolites of the Ravns Storø belt are sheeted with aplites which are concordant with the foliation of the amphibolites but locally cut the folded layering, and which become more and more numerous towards the gneisses. The aplites generally have a quartz dioritic composition, some are garnetiferous, and they are in general gneissified. These border relationships have been more fully described by Windley $e t$ al. (1966) and those of similar amphibolites in the nunatak area of Frederikshabs Isblink by Dawes (1970). The other amphibolites in the area are also sheeted with aplitic material in many cases.

\section{Major structures}

The major fold structures of the region are shown on plate 1 where they are picked out by horizons of amphibolites, anorthosite and 'granite'. Although it is possible that some rocks of the region were deformed before the emplacement of the anorthosite complex, no major structures of such antiquity have been recognised. The amphibolites and anorthosites both appear to have been in existence before the first major structures which appear on the map (plate 1) were formed, and are now parallel horizons. The 'granites' which are shown on the map are of various ages.

The major structural patterns of the north-western and south-eastern parts of the region appear to be different. A major fault zone (the Iterdlak fault) strikes in a NNE-SSW direction across the centre of the region and apparently divides it into two structural domains. Although the movement of the fault is not known, it does not appear to be large and may only emphasise rather than create a structural division of the region. The north-western domain is characterised by enormous interference patterns formed by three episodes of folds $F_{1}$ to $F_{3}$ with axial surfaces normal to each other, whilst the south-eastern domain is characterised by major tight and isoclinal folds which appear to be dominantly of one major episode.

In the north-western domain, the $F_{1}$ folds are now isoclinal and because of way-up evidence within the anorthosite complexes, it is possible in some cases to distinguish between primary anticlines and synclines, but their initial orienta- 
tion and dimensions are unknown. However, because of the generally symmetrical thickness of the anorthosite and amphibolite horizons about the $F_{2}$ and $F_{3}$ fold axes, the $F_{1}$ isoclines appear to have been recumbent with respect to the present land surface before the $F_{2}$ and $F_{3}$ fold episodes.

The $F_{2}$ folds are also isoclinal and possess sub-vertical axial surfaces which trend in a general NE-SW direction. The $\mathrm{F}_{3}$ folds are tight and have sub-vertical axial surfaces which trend in a general NW-SE direction, at a high angle to the axial surfaces of the $F_{2}$ folds. The axial surfaces of the $F_{3}$ folds themselves swing from more NNW-SSE in the north to WNW-ESE in the south.

Syntectonic mineral fabrics indicate that all three deformation episodes were accompanied by metamorphism in either amphibolite or hornblende granulite facies. During the formation of the $F_{2}$ and $F_{3}$ folds, there appears to have been a surprising lack of thickening in fold cores and thinning of fold limbs of the anorthosite and amphibolite horizons. Although there has been strong flattening deformation and some horizons have been attenuated and disrupted, many have survived surprisingly intact, notably the horizons on Qeqertarssuatsiaq and to the north and west of Tasiussarssuaq (plate 1). The widespread preservation of igneous textures and layering in the anorthosite complexes indicates that many of these horizons, however thin, have suffered relatively slight internal deformation.

In the south-eastern domain, the major folds are tight to isoclinal and have steeply dipping axial surfaces. In the north their axial surfaces generally trend E-W and their fold axes plunge moderately to the east, whilst in the south the axial surfaces trend NE-SW and the fold axes plunge to the SW. The folds throughout the south-eastern domain are generally overturned towards the south. In the north they appear to be symmetrical whilst in the south they are asymmetrical with steep southerly dipping limbs and more gently dipping northerly limbs. The relationship between these folds and those in the north-western domain is as yet uncertain, but they may be the same as the $F_{2}$ folds of the north-western domain.

The structural history of the region is longer and more complicated than is apparent from the major folds seen on plate 1. More details of the sequences of minor and major folds within specific areas are described later in this report by Hopgood, Andersen \& Friend, and Walton. So far little detailed correlation has been achieved between the minor structures and tectonic fabrics in different map areas, and the fold chronology $F_{1}-F_{3}$ of the north-western domain is a synthesis of the regional map (plate 1 ).

\section{Chronological notes}

It is supposed that most of the amphibolites in the area are of supracrustal origin and that the anorthosite complexes were emplaced into these supracrustal rocks. It is possible that some of the gneisses represent the basement upon which these 
supracrustals were laid down, but no direct evidence of such a basement has yet been discovered. Layers and inclusions of amphibolite and anorthositic rocks have been found in most gneisses. Both amphibolites and anorthosites show folds belonging to the oldest fold phase recognised. Amphibolite dykes are very rare, but have been found both in gneisses, and amphibolites (e.g. in the supracrustal rocks of the Ravns Storø belt) and the anorthosite complexes. Only few radiometric age determinations have been made, and the age of most of the gneisses and of the amphibolites and anorthositic rocks are largely unknown. On the other hand, it can be clearly demonstrated that part of the gneisses is younger than the amphibolites and anorthosites. Sheets of granitic gneiss cut amphibolites and anorthositic rocks, and the autochthonous granites which form large areas in the southern part of the region formed relatively late in the structural history of the gneisses (Hopgood this issue).

The rocks in the area have undergone a long history of deformation, metamorphism and migmatisation. Axial plane foliations and linear fabrics have developed in association with all major fold phases. Some leucosome veins in the migmatites are isoclinally folded by $F_{1}$, others cross-cut early structures but have themselves been deformed; still others are undeformed and sharply cross-cut the other rocks. No detailed study of the relationship between the metamorphism and migmatisation and the deformation has as yet been made.

The rocks in the north-western part of the area belong to the hornblende granulite facies, but they have been partly retrogressed to amphibolite facies rocks. The hornblende granulite facies metamorphism seems to be rather late (or lasted rather long), since hypersthene has been found aligned along the axes of $F_{3}$ folds. The rocks in the southern part of the area belong to the amphibolite facies, and they do not appear to have been retrogressed from granulite facies. We do not yet have good criteria to distinguish between retrograde and prograde amphibolite facies.

The Ilivertalik granite has an interesting chronological position. It cuts discordantly across foliated and migmatized amphibolite and streaky gneiss which themselves locally contain inclusions of rocks of the anorthosite complex. It generally possesses a steep linear fabric (probably $F_{3}$ ) and a hornblende granulite facies mineralogy. Locally the Ilivertalik granite is migmatised and cut by sheets of younger granite. Ilivertalik granites form large outcrops in the northern part of the region and are easily recognizable rocks, and therefore provide a good time marker. Radiometric dating of these rocks is under progress.

Post-orogenic dolerite dykes are common throughout the area and belong to several generations. These dykes have not been shown on the map of plate 1 . 


\section{References}

Black, L. P., Gale, N. H., Moorbath, S., Pankhurst, R. J. \& McGregor, V. R. 1971: Isotopic dating of very early Precambrian amphibolite facies gneisses from the Godthaab district, West Greenland. Earth planet. Sci. Lett. 12, 245-259.

Dawes, P. R. 1970: Bedrock geology of the nunataks and semi-nunataks in the Frederikshaibs Isblink area of southern West Greenland. Rapp. Grønlands geol. Unders. 29.

Ghisler, M. 1970: Pre-metamorphic folded chromite deposits of stratiform type in the early Precambrian of West Greenland. Miner. Deposita, 5, 223-236.

Ghisler, M. \& Windley, B. F. 1967: The chromite deposits of the Fiskenæesset region, West Greenland. Rapp. Grønlands geol. Unders. 12.

Gormsen, K. 1971: En geologisk undersøgelse af det chromitførende Fiskenæsset kompleks omkring Taseq, Vestgrønland. Unpublished thesis, University of Copenhagen.

Herd, R. K. 1972: The petrology of the sapphirine-bearing and associated rocks of the Fiskenæsset complex, West Greenland. Unpublished thesis, University of London.

Kalsbeek, F., Ghisler, M. \& Thomsen, B. in press: Fluvial sands from the Fiskenæesset region, south-west Greenland, their composition and use for geochemical studies and for prospecting. Bull. Grønlands geol. Unders. (also Meddr Grønland).

Kornerup, A. 1879: Geologiske Iagttagelser fra Vestkysten af Grønland (62 $15^{\prime}-64^{\circ} 15^{\prime}$ N.B.). Meddr Grønland 1, 77-139.

McGregor, V. R. 1973: The early Precambrian gneisses of the Godthåb district, West Greenland. Phil. Trans. R. Soc. Lond. A, 273, 343-358.

Pulvertaft, T. C. R. 1968: The Precambrian stratigraphy of western Greenland. Rep. 23rd int. geol. Congr. Czechoslovakia, 1968, 4, 89-107.

Ramberg, H. 1952: The origin of metamorphic and metasomatic rocks. Univ. Chicago Press.

Ronov, A. B. \& Yaroshevsky, A. A. 1969: Chemical composition of the earth's crust. In Hart, P. J. (editor): The earth's crust and upper mantle, 37-57. Washington: American geophysical Union.

Sørensen, H. 1955: Anorthosite from Buksefjorden; West Greenland. Meddr dansk geol. Foren. 13, 31-41.

Windley, B. F. 1967: On the classification of the West Greenland anorthosites. Geol. Rdsch. 56, 1020-1026.

Windley, B. F. 1969: Evolution of the early Precambrian basement complex of southern West Greenland. Spec. Pap. geol. Ass. Can. 5, 155-161.

Windley, B. F. 1971: The stratigraphy of the Fiskenæsset anorthosite complex. Rapp. Grønlands geol. Unders. 35, 19-21.

Windley, B. F., Henriksen, N., Higgins, A. K., Bondesen, E. \& Jensen, S. B. 1966: Some border relations between supracrustal and infracrustal rocks in South-West Greenland. Rapp. Grønlands geol. Unders. 9.

Windley, B. F., Herd, R. K. \& Bowden, A. A. in press: The Fiskenæsset complex, West Greenland. Part I: A preliminary study of the stratigraphy, petrology and whole-rock chemistry. Bull. Grønlands geol. Unders. (also Meddr Grønland 196, 2).

Windley, B. F. \& Smith, J. V. in press: The Fiskenæsset complex, West Greenland. Part II: General mineral chemistry. Bull. Grønlands geol. Unders. (also Meddr Grønland). 